\title{
ANALISIS EFISIENSI DAN EFEKTIVITAS PENGGUNAAN ANGGARAN PEMELIHARAAN JEMBATAN PADA DINAS PEKERJAAN UMUM KABUPATEN ENDE
}

\author{
Oleh \\ 1) Katarina Meo \\ Mahasiswa Prodi Akuntansi \\ 2) Yulita Londa \\ Dosen Prodi Akuntansi \\ e-mail: selolitalonda@yahoo.com \\ 3) Nuraini Ismail \\ Dosen Prodi Akuntansi \\ e-mail: nurainiismail100@gmail.com
}

\begin{abstract}
ABSTRAK
Tujuan dari penelitian ini adalah untuk menganalisis efisiensi dan efektivitas penggunaan anggaran pemeliharaan jembatan untuk Dinas Pekerjaan Umum Kabupaten Ende tahun 20152017. Analisis data yang digunakan adalah analisis kuantitatif dengan memperhitungkan efisiensi dan efektivitas anggaran pemeliharaan jembatan. Penelitian bersifat menjelaskan hal-hal yang berkaitan dengan pengujian hipotesis dan bersifat deskriptif juga memuat uraianuraian yang digunakan dalam penelitian yaitu dengan cara mengumpulkan data.

Data yang dikumpulkan dalam penelitian ini adalah data anggaran pembangunan jembatan tahun 2015-2017 yang diperoleh dari Dinas Pekerjaan Umum Kabupaten Ende dan data mengenai realisasi fisik dan realisasi anggaran pembangunan jembatan kabupaten di Kabupaten Ende pada Dinas Pekerjaan Umum. Hasil penelitian ini menunjukkan bahwa anggaran dan realisasi fisik sangat mempengaruhi efisiensi dan efektivitas pembangunan jembatan.
\end{abstract}

Kata kunci: Efisien, Efektifitas, anggaran

\section{ABSTRACT}

The purpose of this study is to analyze the efficiency and effectiveness of the use of the bridge maintenance budget for the public works service of Ende district from 2015-2017. The data analysis used is quantitative analysis by calculating the efficiency and effectiveness of the bridge maintenance budget. The research has the character of explaining matters relating to hypothesis testing and in its descriptive nature it also contains descriptions used in the research, namely by collecting data.

The data collected in this study are the bridge construction budget data from 2015-2017 which were obtained from the Public Works Office of Ende Regency and data regarding the physical realization and realization of the district bridge construction budget in Ende Regency at the Public Works Office. The results of this study indicate that the budget and physical realization greatly influence the efficiency and effectiveness of bridge construction. 
ANALISIS EFISIENSI DAN EFEKTIVITAS PENGGUNAAN ANGGARAN PEMELIHARAAN

JEMBATAN PADA DINAS PEKERJAAN UMUM KABUPATEN ENDE - ${ }^{1)}$ Katarina Meo, ${ }^{2)}$ Yulita

Londa, ${ }^{3)}$ Nuraini Ismail

\section{Key words: Efficient, Effectiveness, budget}

\section{PENDAHULUAN}

Negara Republik Indonesia saat ini sedang giat-giatnya melaksanakan pembangunan disegala bidang dalam rangka mewujudkan cita-cita nasional, yaitu untuk melindungi segenap bangsa Indonesia dan seluruh tumpah darah Indonesia, memajukan kesejateraan umum, mencerdaskan kehidupan Bangsa dan ikut melaksanakan ketertiban dunia yang berdasarkan perdamaian abadi dan keadilan sosial, sesuai dengan yang disebut dalam UUD 1945. Dalam UU No.25 tahun 2004 tentang perencanaan pembangunan nasional menyatakan bahwa peningkatan dan pembangunan dalam perencanaan dan pelaksanaan harus dapat memenuhi persyaratan yang ada yaitu tepat mutu, tepat biaya, tepat waktu dan bermanfaat untuk kepentingan masyarakat, karena organisasi sektor publik sering dinilai sebagai sarana efisiensi, pemborosan, serta institusi yang selalu merugi.

Undang-undang Peraturan Daerah Nomor 9 Tahun 2010 tentang pelaksanaan pekerjaan pembangunan, peningkatan dan pemeliharaan jalan dan jembatan. Bahwa dalam rangka meningkatkan kesejahteraan rakyat, maka pembangunan infrastruktur terutama jalan dan jembatan merupakan prioritas guna meningkatkan perekonomian rakyat. Efisiensi sebagai usaha untuk mencapai hasil yang maksimal dengan menggunakan sumber daya yang tersedia, yang meliputi sumber daya alam, modal dan manusia dalam suatu waktu. Menurut Wirapadi, efisiensi dapat dilihat dari dua segi yaitu pertama, hasil yang telah dicapai dan kedua adalah usaha telah dilakukan. Suatu kegiatan dapat disebut efisiensi jika usaha yang telah dilakukan memberikan output yang maksimal, baik dari jumlah maupun kualitas. Suatukegiatan juga dikatakan efisiensi jika dengan usaha minimum dapat mencapai output tertentu.

Pembangunan daerah sebagai bagian integral dari pembangunan nasional untuk memberikan kesempatan bagi upaya pengembangan yang demokratis dan kinerja daerah dalam rangka peningkatan kesejahteraan masyarakat. Berdasarkan pemaparan diatas,sangat jelas bahwa pengukuran nilai efisiensi ini sangat dibutuhkan oleh instansi pemerintahan dalam menjalankan tugasnya.Berbagai tuntutan agar pemerintah dapat memberikan pelayanan secara cepat dan efektif sudah menjadi tuntutan umum dimasyarakat belakangan ini. Untuk itu, setiap instansi pemerintahan harus sepatutnya memperbaiki kinerja yang lebih lengkap untuk mencapai visi misi instansi yang bersangkutan. 
Pembangunan daerah sebagai bagian integral dari pembangunan nasional untuk memberikan kesempatan bagi upaya pengembangan yang demokratis dan kinerja daerah dalam rangka peningkatan kesejahteraan masyarakat. Berdasarkan pemaparan diatas,sangat jelas bahwa pengukuran nilai efisiensi ini sangat dibutuhkan oleh instansi pemerintahan dalam menjalankan tugasnya.Berbagai tuntutan agar pemerintah dapat memberikan pelayanan secara cepat dan efektif sudah menjadi tuntutan umum dimasyarakat belakangan ini. Untuk itu,setiap instansi pemerintahan harus sepatutnya memperbaiki kinerja yang lebih lengkap untuk mencapai visi misi instansi yang bersangkutan.

\section{Kajian Pustaka}

\subsection{Konsep Pemeliharaan Jembatan}

Keberadaan jembatan sangat terkait dengan peningkatan volume kendaraan jika suatu ruas jalan dengan persimpangan sebidang yang ada ternyatasudah menimbulkan kemacetan atau mengalami masalah kapasitas jembatan.

Pemeliharaan harus dilihat secara dinamis bukan dilihat dari konsep statis yang selama ini sering kita anggap sebagai suatu kesalahan yang wajar.Pemeliharaan pada dasarnya suatu orentasi dan kegiatan usaha yang tanpa akhir.

Menurut Soetomo (2008) pembangunan merupakan suatu proses perubahan dapat dipahami dan dijelaskan dengan cara yang berbeda. Perbedaan tersebut dapat dilihat dalam hal sumber atau faktor yang mendorong perubahan tadi, misalkan yang ditempatkan dalam posisi lebih dominan,sumber perubahan eksternal atau internal.Siagan (1994) memberikan pengertian pembangunan sebagai suatu usaha atau rangkaian usaha pertumbuhan dan perubahan yang berencana dan di lakukan secara sadar oleh suatu Bangsa, Negara dan Pemerintah menuju modernisasi dalam rangka pembinaan bangsa. Portes (1976) pembangunan sebagai transformasi ekonomi,sosial dan budaya.

Dimana realita pembangunan dilakukan oleh siapapun serta dalam bidang apapun pasti mengarah pada perubahan sosial baik dalam bidang material maupun nonmaterial. Penggerak utama pembangunan adalah masyarakat. Masyarakat berusaha untuk melakukan pembangunan dengan tujuan dapat mewujudkan kesejahteraan manusia. (kebutuhan dan tuntunan hidup manusia). Pembangunan merupakan proses perubahan yang direncanakan untuk memperbaiki berbagai aspek kehidupan masyarakat. 
Makna penting dari pembangunan adalah adanya kemajuan atau perbaikan dalam mencapai suatu perubahan yang lebih baik,karena perubahan yang dimaksud adalah menuju arah peningkatan dari keadaan semula.Dengan demikian pada dasarnya pembangunan tidak dapat dipisahkan dari pertumbuhan dalam arti pembangunan dapatmenyebabkan terjadinya pertumbuhan dan pertumbuhan akan terjadi sebagai akibat adanya pembangunan.

\subsection{Konsep Pembangunan Infrastruktur Sarana dan Prasarana Pemeliharaan Jembatan}

Pemeliharaan Pembangunan dilakukan guna menunjang dan meningkatkan mutu kehidupan masyarakat. Segala aspek-aspek dan segi kehidupan masyarakat mengalami berbagai perkembangan baik dari yang terkecil hingga yang terbesar. Keseluruhan ini merupakan bentuk keinginan masyarakat untuk menuju kearah yang lebih baik. Jembatan merupakan lintasan yang menghubungkan tempat yang satu dengan yang lain yang digunakan untuk menyeberangi jurang dan lainnya, agar dapat meningkatkan pembangunan diberbagai bidang.

\subsection{Konsep PemeliharaanJembatan}

Pemeliharan jembatan tidak jauh berbeda dengan pemeliharaan jalan,perbedaan yang ada bahwa jembatan sering terjadi kerusakan diluar kemampuan masyarakat untuk memperbaiki hal tersebut dikarenakan banyaknya bagian jembatan yang harus memiliki daya tahan yang cukup tinggi dan bagian ini tidak dapat di perbaiki dengan metode yang sederhana saja.Perbaikan jembatan tidak hanya penyumbangan tenaga kerja saja akan tetapi sering memerlukan pembelian bahan yang sulit terjangkau oleh kemampuan ekonomi masyarakat.

\subsection{Anggaran PemeliharaanJembatan}

Anggaran yang disusun harus sesesuai dengan aktifitas yang direncanakan dalam periode mendatang harus disusun didalam suatu anggaran lengkap. Karena tanpa memiliki anggaran lengkap,maka aktifitas yang dilaksanakan tetapi tidak memiliki anggaran tidak bisa dilaksanakan dengan baik.Jika aktifitas yang tidak memiliki anggaran tersebut tetap di upayakan untuk dilakasanakan,maka aktifitas tersebut tidak dapat di nilai hasilnya.

Defenisi anggaran menurut para ahli. Anggaran (budget) adalah rencana operasi keuangan yang mencakup estimasi pengeluaran yang diusulkan,dan sumber pendapatan yang diharapkan untuk membiayai dalam periode waktu tertentu (Bastian,2006:164). Kluver (2002) 
ANALISIS EFISIENSI DAN EFEKTIVITAS PENGGUNAAN ANGGARAN PEMELIHARAAN

JEMBATAN PADA DINAS PEKERJAAN UMUM KABUPATEN ENDE - 1)Katarina Meo, ${ }^{2)} Y u l i t a$

Londa, ${ }^{3)}$ Nuraini Ismail

mengatakan anggaran line-item menekankan pengendalian dan alokasi sumber daya yang ditetapkan sesuai dengan input. Manajer diberi wewenang untuk menggunakan.

\subsection{Efisiensi dan Efektivitas dan Pengukuran Nilai Hasil}

dana yang memungkinkan mereka untuk melaksanakan fungsi dan tanggung jawabannya. Pendapat Markus Zahnd (2006) efisiensi berarti tepat atau sesuai untuk mengerjakan sesuatu dengan tidak membuang-buang waktu,tenaga dan biaya.Berdasarkan pendapat diatas,maka efisiensi dapat diartikan sebagai suatu standar untuk menilai seberapa besar usaha yang dilakukan oleh pelaksana suatu kegiatan atau kebijakan dalam mencapai tujuan dan sasaran yang akan dicapai.Menurut Wilian N.Dunn (2003) berpendapat bahwa efisiensi berkenaan dengan jumlah usaha yang diperlukan untuk menghasilkan tingkat efektivitas tertentu.

Efisiensi biasanya ditentukan melalui perhitungan biaya perunit produk atau layanan kebijakan mencapai efektivitas tertinggi dan biaya terkecil dinamakan efisiensi. Konsep efektivitas dalam melakukan suatu pekerjaan diharapkan mampu mencapai hasil dan tujuan yang baik. Kata efektifitas berasal dari kata efektif yang artinya hasil, pengaruh atau akibat(Y. Zuylkarnaen; 2000:75). Dalam kamus besar Bahasa Indonesia, efektifitas adalah ukuran hasil tugas atau pencapaian tujuan. Efektivitas berasal dari kata efektif yang mengandung pengertian dicapainya keberhasilan dalam mencapai tujuan yang telah ditetapkan. Efektivitas juga disebut sebagai hasil guna. Efektivitas selalu terkait dengan hubungan antara hasil yang diharapkan dengan hasil yang sesungguhnya dicapai (Herlina,2009)menurut Siagan dan Edi siswadi (2012:86) mengartikan efektifitas adalah pemanfaatan sumber daya, sarana dan prasarana dalam jumlah tertentu yang secara sadar diterapkan sebelumnya untuk menghasilkan sejumlah barang atas jasa kegiatan yang dijalankannya. Efektivitas menunjukan keberhasilan dari segi tercapai tidaknya sasaranyang telah ditetapkan. Jika hasil kegiatan mendekati sasaran, berarti makin tinggi efektivitasnya.

\section{Metode Penelitian}

Lokasi penelitian dilakukan pada Dinas Pekerjaan Umum Kabupaten Ende, Bidang Bina Marga yang beralamat di Jalan Banteng Nomor. 1 Kabupaten Ende. Jenis data yang digunakan dalam penelitian ini adalah data kualitatif.Menurut Sugyono data kualititatif adalah memberikan gambaran, menganalisa dan menyajikan data dalam bentuk angka.Jenis data ini 
ANALISIS EFISIENSI DAN EFEKTIVITAS PENGGUNAAN ANGGARAN PEMELIHARAAN

JEMBATAN PADA DINAS PEKERJAAN UMUM KABUPATEN ENDE - 1)Katarina Meo, ${ }^{2) Y u l i t a ~}$

Londa, ${ }^{3}$ Nuraini Ismail

memberikan gambaran, menganalisa dan menyajikan data yang berupa laporan keuangan yang peneliti dapat dari Kantor Dinas Pekerjaan Umum Kabupaten Ende. Sumber data dalam penelitian ini adalah data primer dan data sekunder: Menurut umar( 2003:56 ) data primer adalah data yang diperoleh langsung di lapangan oleh peneliti sebagai obyek penulisan. Metode wawancara mendalam atau in-depth interview dipergunakan untuk memperoleh data dengan cara diwawancara. Data primer data yang peneliti dapat secara langsung melalui wawancara dengan bapak Stanis sebagai bendahara keuangan di Kantor Dinas Pekerjaan Umum Kabupaten Ende. Data sekunder merupakan data yang bersumber dari kajian pustaka dan catatan-catatan yang dimiliki instansi tersebut.

Teknik pengumpulan data yang digunakan yaitu dengan melakukan Studi pustaka yaitu:Penulis membaca dan mempelajari buku-buku, literature, artikel-artikel dan berbagai sumber yang berhubungan dengan materi penelitian. Penulis melakukan penelitian langsung pada lokasi atau objek kantor Dinas Pekerjaan Umum Kabupaten Ende. Teknik pengumpulan data ini ditempuh dengan cara sebagai berikut: Observasi yaitu mengadakan pengamatan secara langsung pada Kantor Dinas Pekerjaan Umum Kabupaten Ende, dan Wawancara yaitu untuk memperoleh data yang jelas menulis melakukan wawancara secara langung dengan pegawai pada Dinas Pekeraan Umum. Teknik Analisis Data: Dalam penelitian ini ada dua pengukuran yang digunakan yaitu pengukuran nilai efisiensi dan penukuran nilai hasil. Analisis yang dimaksud untuk menganalisa data-data yang telah ada. Pengukuran Nilai Efisiensi. Pengukuran efisiensi dapat diukur dengan membandingkan antara output dan input (Both dalam Soamole,2007).

\section{Hasil Penelitian dan Pembahasan}

Berdasarkan tujuan penelitian, maka dapat disimpulkan bahwa Kabupaten Ende memiliki letak yang cukup strategis yaitu menghubungkan kabupaten yang satu dengan kabupaten yang lainnya. Infrastruktur jembatan jalan sangat penting untuk mendistribusikan barang dan jasa. Akses yang mudah dan lancar akan meningkatkan perekonomian, oleh karena itu jembatan dan jalan harus dibangun dan dipelihara. Program pembangunan daerah bukan hanya untuk membiayai kegiatan operasi dan pembangunan jalan dan jembatan kabupaten saja tetapi juga kegiatan lainnya yang menjadi tanggung jawab pemerintah. Kegiatan pembangunan jembatan digunakan untuk meningkatkan prasarana jalan dan jembatan dalam rangka memenuhi kebutuhan prasarana masyarakat. 


\section{Kesimpulan Dan Saran}

Berdasarkan penjelasan diatas maka saran-saran sebagai berikut: Pada Dinas Pekerjaan Umum dengan bertambahnya anggaran dari pemerintah setiap tahun khususnya pada alokasi anggaran pembansgunan jembatan itu, bukan hanya efisiensi saja yang dilakukan oleh pemerintah tetapi efektivitas juga harus juga penting. Dengan cara anggaran yang digunakan dalam pemeliharaan harus harus tepat agar tidak membuang- buang waktu. Hasil pembangunan jembatan merupakan target yang ingin dicapai oleh pemerintah yang langsung dirasakan oleh masyarakat. Maka perlu dilakukan pengawasan oleh dinas terkait dalam mengawasi kinerja dilapangan.

\section{DAFTAR PUSTAKA}

Agung Ari Wickas (2007). PengukuranKinerjaProyek Pembangunan Jalan dan Jembatan Gedong 11 Pada Dinas Pekerjaan Umum Kabupaten Magetang.

Bastian (2006:164), Indra (2006). Sistem Akuntansi Sektor Publik. Edisi Jakarta Sulemba Empat

Both, Aven Purwanta Sauri, (2014). Analisis Efisiensi dan Efektivitas Penggunaan Anggaran Pemeliharaan Jembatan Kota Pare-Pare

Guritno (1993). Ekonomi Sektor Publik Edisi-III, BPFC, Yogyakarta

Kluver, Ron (2002). Budgeting Program Accounttability In Local Government. University Of Melbourne

Mahmudi, (2005). Manajement Kinerja SektorPublik, Edisi I. Yogyakarta: UPP AMP YKPN Naasra (1978) mengidentifikasi tentang pemeliharaan

UUD No 25 tahun 2004 tentang perencanaan pembangunan nasional

UUD Perda No 9 tahun 2010 tentang pelaksanaan pekerjaan pembangunan

Siagan Sondong P. 1994. Sumber Daya Manusia Kepemimpinan dan Perilaku Administrasi. Jakarta: BumiAksara

Soetomo. 2008. Masalah Sosial dan Upaya Pemecahan. Yogyakarta: Pustaka Pelajar

Wahyu Ardiansyah. 2007. Pengukuran Kinerja Proyek

Wilian N. Dunn. 2003. Analisis Kebijakan Publik. Yogyakarta: Gadjah Mada University Press Y. Zulkarnaen (2005: 75). Kamus Praktis Bahasa Indonesia. Surabaya: Karya Utama

Zahud, Markus. 2006. Perancangan Kota Secara Terpadu. Yogyakarta: Kanisius 